\title{
Testing of The Surface Roughness Parameters of AluminiUm-Lithium Parts MaChined by Milling
}

\author{
Danijel Sogorovic \& Anica Knezevic
}
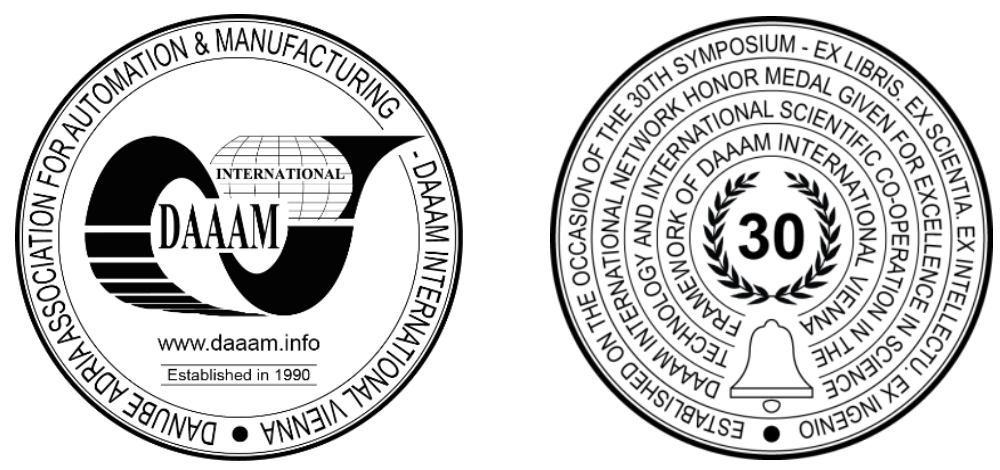

This Publication has to be referred as: Sogorovic, D[anijel] \& Knezevic, A[nica] (2019). Testing of the Surface Roughness Parameters of Aluminium-Lithium Parts Machined by Milling, Proceedings of the 30th DAAAM International Symposium, pp.0148-0154, B. Katalinic (Ed.), Published by DAAAM International, ISBN 978-3-902734-22-8, ISSN 1726-9679, Vienna, Austria

DOI: $10.2507 / 30$ th.daaam.proceedings.019

\begin{abstract}
This paper examines the influence of technological parameters (elements of the cutting process) on the roughness of the surface in the milling process of a part of aluminium-lithium alloy. The aim of the paper is to analyse the impact of cutting speed, feed speed and depth of cut on the roughness parameter $\mathrm{R}_{\mathrm{a}}$. The machine tool, tool used, the material and the device for measuring of the roughness parameters are shown. An adequate mathematical model was developed by statistical analysis, which describes the effect of technological parameters on roughness. The results of the experiments are presented in table and graphic and are suitable only for observed cutting conditions, used tools and material.
\end{abstract}

Keywords: technological parameters; roughness parameters; milling; testing.

\section{Introduction}

Most manufacturing companies determine the technological parameters of machining based on an experience of workers or recommendations from various manuals. The modernization of production is constantly increasing over the past decades, so it is essential to focus on economic analysis in combination with technological knowledge in order to make investments in production more logical and no random. Aluminium-lithium alloy has a good mechanical properties for various constructions such as airplane parts with significant lower heaviness.

The production process is enabled by the certain elements of the cutting process i.e. technological parameters. There are specific technological parameters for machining with cutting whose value derive from the ability of the technical system in order to solve the requirements of production. For the each process it is necessary to specify the technological parameters because they directly affect at the efficiency of the milling process. [1] The efficiency of the process cannot be increased in any case, because there is a functional relation between the elements of the cutting process which results in individual value.

Measurement and evaluation of surface texture have seen major qualitative advances in recent years. Leading producers of measuring instruments (Hommel, Carl Zeiss, and others) have responded actively to new requirements. Surface texture is frequently checked by means of single-purpose measuring instruments [2]. Many authors researched the surface roughness. Zaujec at all [3] studied the influence of CAM strategies on surface roughness. Hronek \& Zetek 
[4] observed how cutting edge radius influence on surface roughness when milling nickel alloy. Kubátová \& Melichar [2] have shown how the scanning speed when measuring effects on surface roughness. Zetkova et all [5] investigated the influences of technological parameters on the surface quality in process of Water jet cutting. Mou et all [6] performed the experimental study of surface roughness of aluminium-lithium alloy by face milling but this study observed cryogenic face milling.

This paper examines the influence of technological parameters on the surface roughness in end milling process without cooling of parts made by aluminium-lithium alloy.

\section{Experiment}

With this experiment the influence of technological parameters (cutting speed, feed speed and depth of cut) on surface roughness $R_{a}$ when end milling is analysed. With help of the results obtained in this experiment it is necessary to define a mathematical model which describes this process. The input parameters in the experiment are:

- cutting speed - v [m/min],

- feed speed $-\mathrm{s}_{\min }[\mathrm{mm} / \mathrm{min}]$,

- depth of cut $-\delta[\mathrm{mm}]$

The output parameter is arithmetic average roughness $\mathrm{R}_{\mathrm{a}}$ and function of machinability:

$$
\mathrm{R}_{\mathrm{a}}=\mathrm{f}\left(\mathrm{v}, \mathrm{s}_{\min }, \delta\right)
$$

For determination of surface roughness in relation with input sizes the fractional experimental design $2^{3}$ is being chosen [7]. It has 3 factors and each factor has two level and there are 8 experimental conditions in this design. This composition of experimental conditions is being added a number of experiments $\left(\mathrm{n}_{0}=4\right)$ in the central point of the plan. So, the total number of experiments is:

$$
\mathrm{N}=2^{3}+4=12
$$

\subsection{Equipment for the experiments}

The machine tool is milling machine Prvomajska G01 [8] (Fig.1) made in Croatia (former YU) which is placed in laboratory at University of Mostar. This machine has the transmission reduction for main spindle with 17 rotational speeds $\left(63-5000 \mathrm{~min}^{-1}\right)$ and transmission reduction for feed motion with 12 feed speed $(12-450 \mathrm{~mm} / \mathrm{min})$. The ranges of rotational speed and rate of feed speed are good and they fully satisfied the values of input sizes of experiments. This machine tool is classical and produced before 40 years, so it is impossible to determine and adjust the feed per tooth $\mathrm{s}_{\mathrm{z}}$ (only by use of the mathematical equation).

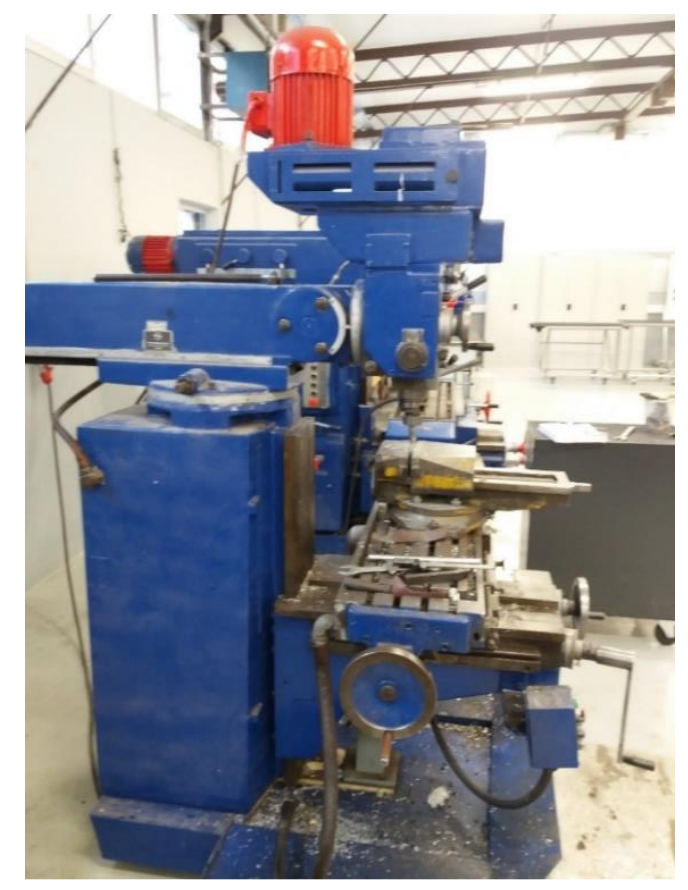

Fig. 1. Milling machine Prvomajska G-01 
For milling of testing surfaces, the end milling cutter with 3 teeth with diameter $\varnothing 15 \mathrm{~mm}$, made by HSS and produced in one SME [9].

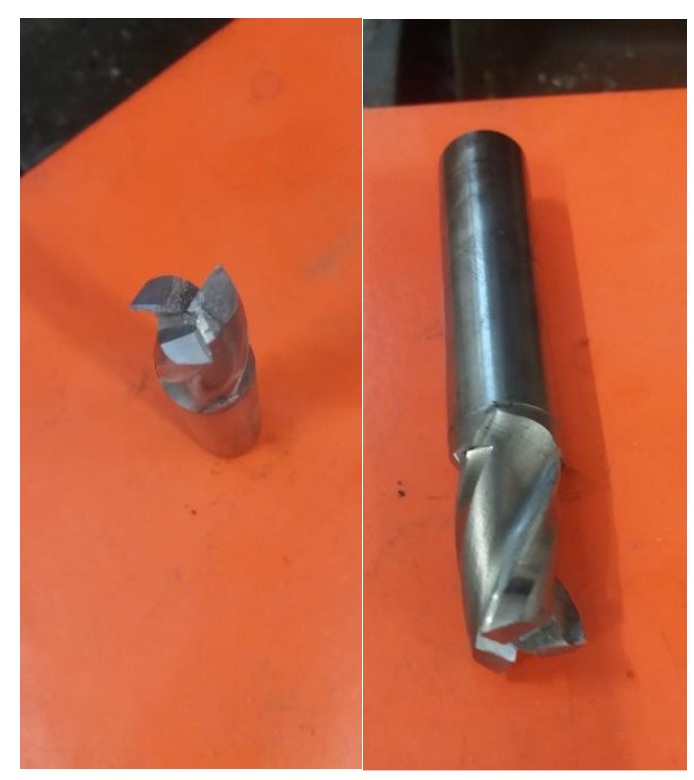

Fig. 2. End mill used in experiments

The samples made by aluminium-lithium alloy are used during the testing. This alloy is developed in airplane industry due to their good mechanical properties and low density and specific heaviness.

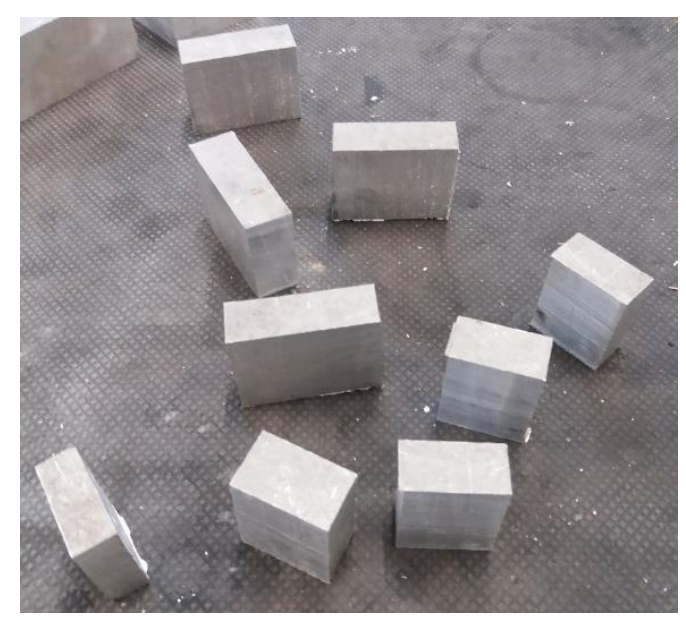

Fig. 3. The samples before machining

For the testing of the surface roughness, following device is used:

- Device name: Hommel-Etamic W5,

- Producer: Hommel-Etamic GmbH, Alte Tuttlinger Str. 20, D- 78056 Villingen - Schwenningen

- Version 1.0

- Number of device: 10050286

This device [10] is only used in testing of surface roughness in accordance with standards. The device may only be operated in perfect technical condition and not in heavily dust-contaminated, chemically aggressive, explosive or radioactive environment. Hommel-Etamic W5 is used for simply wireless measurement of roughness:

- flat surfaces,

- shafts,

- bore holes

- concave and convex surfaces. 


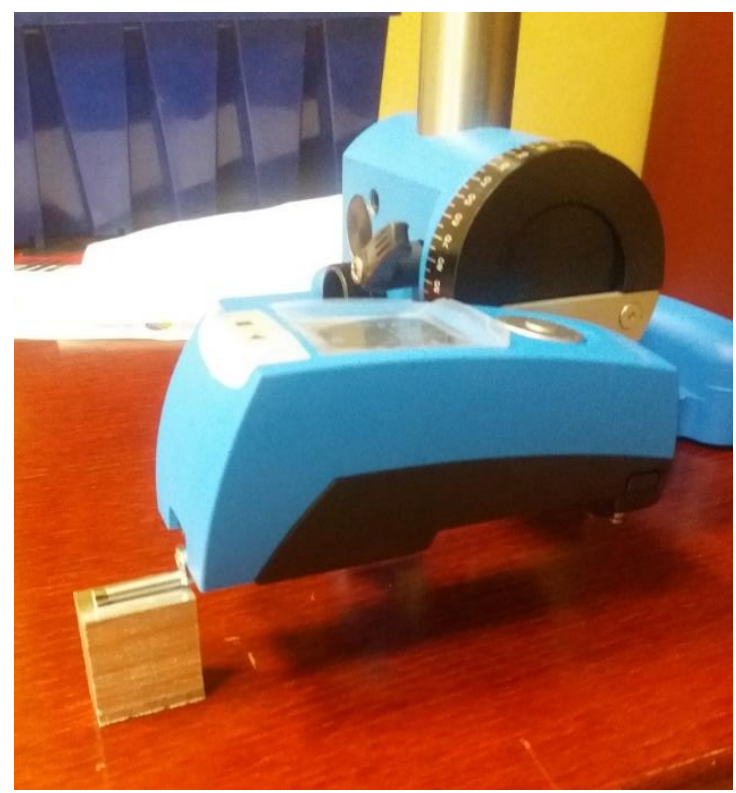

Fig. 4. Hommel-etamic W5

\subsection{Performing of the experiments}

Before the performing of the experiments it is necessary to make the table of level of factors and table of experimental conditions [11].

\begin{tabular}{|c|c|c|c|}
\hline Factors & $\mathrm{X}_{, \mathrm{im}} \min$ & $\mathrm{X}_{\mathrm{i}}, \mathrm{Sr}$ & $\mathrm{X}_{\mathrm{i}}, \max$ \\
\hline $\mathrm{v}[\mathrm{m} / \mathrm{min}]$ & 26,39 & 42,41 & 67,85 \\
\hline$\delta[\mathrm{mm}]$ & 1 & 2 & 4 \\
\hline $\mathrm{s}_{\min }[\mathrm{mm} / \mathrm{min}]$ & 14 & 200 & 500 \\
\hline $\mathrm{Cod}$ & -1 & 0 & 1 \\
\hline
\end{tabular}

Table 1. Level of factors

\begin{tabular}{|c|c|c|c|c|c|}
\hline \multirow{2}{*}{ No. } & \multirow{2}{*}{ No. of measuring } & \multicolumn{3}{|c|}{ Input factors } & Output factor \\
\cline { 3 - 6 } & & $\mathrm{v}$ & $\delta$ & $\mathrm{s}_{\min }$ & $\mathrm{R}_{\mathrm{a}}$ \\
\hline 1. & 8 & 67.85 & 4 & 500 & 1.071 \\
\hline 2. & 4 & 67.85 & 4 & 14 & 0.136 \\
\hline 3. & 1 & 67.85 & 1 & 500 & 1.01 \\
\hline 4. & 12 & 67.85 & 1 & 14 & 0.182 \\
\hline 5. & 7 & 42.41 & 4 & 500 & 0.804 \\
\hline 6. & 10 & 42.41 & 4 & 14 & 0.243 \\
\hline 7. & 3 & 42.41 & 1 & 500 & 0.752 \\
\hline 8. & 5 & 42.41 & 1 & 14 & 0.205 \\
\hline 9. & 6 & 26.39 & 2 & 200 & 1.565 \\
\hline 10. & 9 & 26.39 & 2 & 200 & 1.323 \\
\hline 11. & 11 & 26.39 & 2 & 200 & 1.368 \\
\hline 12. & 2 & 26.39 & 2 & 200 & 1.231 \\
\hline
\end{tabular}

Table 2. Experimental conditions 
Experimental conditions and the choice of experimental design plan is performed by using of software programme Design - Expert 11. After the input of values of surface roughness (obtained from the experiments) in programme Design - Expert 11, the results are shown in Figure 5.

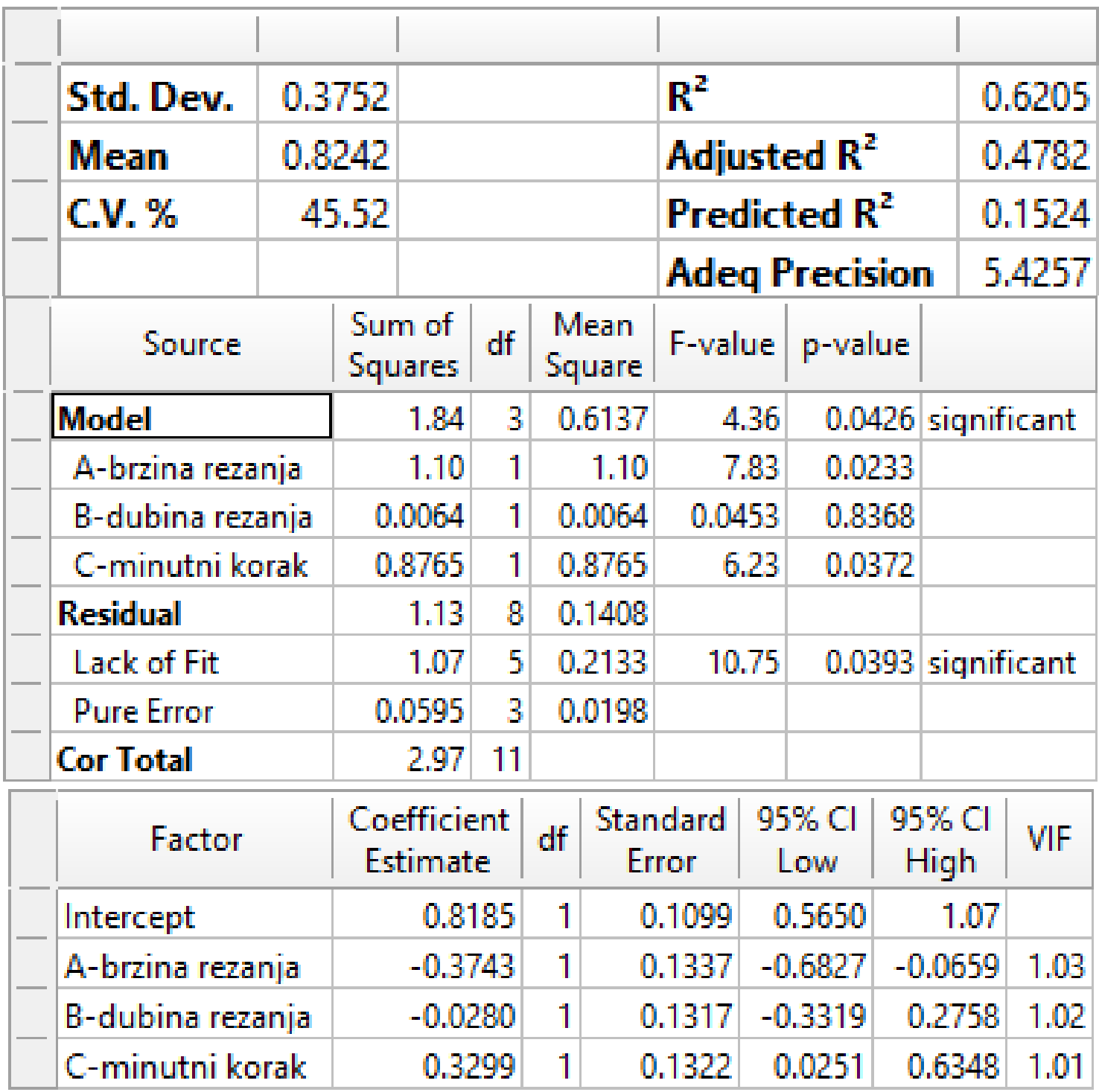

Fig. 5. The analyse of the results of experiments [11]

The statistical significance of mathematical model is depends on value of empiric F-value and p-value in table ANOVA. The F-value is 4.36 and it shows that chosen model is significant i.e. the model which describes the arithmetic average roughness is adequate and reliable. The p-value less than 0,500 shows a significance of two factors in model. In this case, the cutting speed $(\mathrm{p}=.0 .233)$ and feed speed $(0.0372)$ are significant. Third input parameter, depth of cut is not significant $(\mathrm{p}=0.8386)$.

Coded model of roughness is:

$\mathrm{R}_{\mathrm{a}}=0,8185-0,3743 \cdot \mathrm{A}-0,0280 \cdot \mathrm{B}+0,3299 \cdot \mathrm{C}$

De-coded model of roughness is:

$\mathrm{Ra}=1,36709-0,018055 \cdot \mathrm{v}-0,018694 \cdot \delta+0,001358 \cdot \mathrm{s}_{\min }$

Next two figures show the influence of two significant technological parameters (cutting speed and feed speed) on the surface roughnes which are analised through experiments and drawn by, already mentioned, software programme Design - Expert 11. 


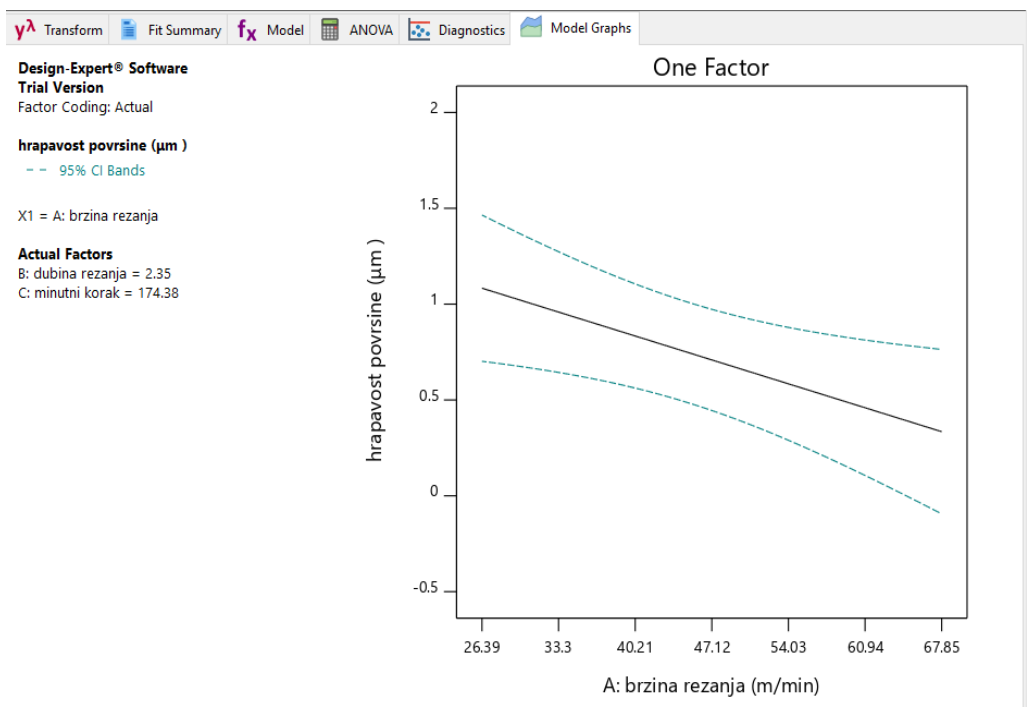

Fig, 6. The influence of the cutting speed on surface roughness

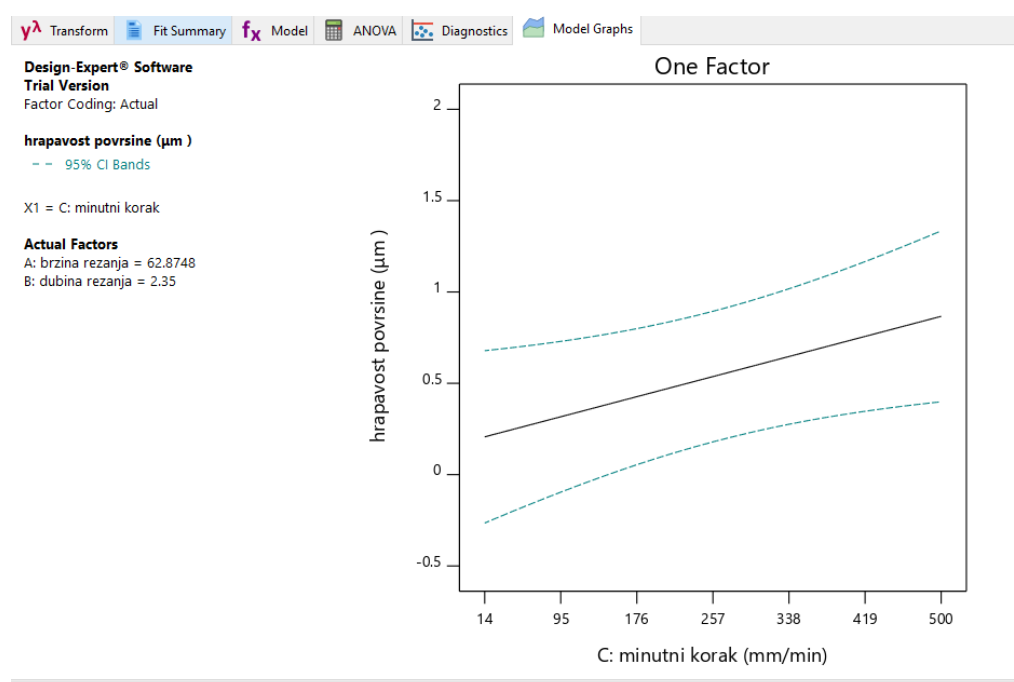

Fig. 7. The influence of the feed speed on surface roughness

The next figure presents the diagram of relation between surface roughness and two significant technological parameters (cutting speed and feed speed) with minimal value of third technological parameter which has no significant influence (depth of cut).
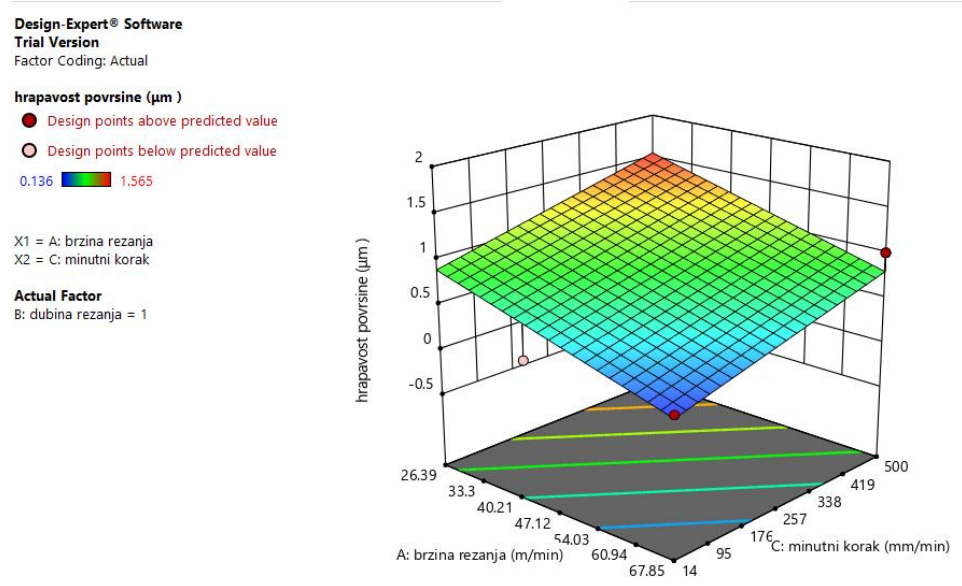


\section{Conclusion}

There are many factors which influence on roughness of machined surface but one of the most important are technology parameters. The performed experiments shows that the depth of cut has no significant influence on the roughness of machined surface. The values of depth of cut in this experiments $(1-4 \mathrm{~mm})$ are not good chosen, so the future research will consider bigger values of depth of cut and in that way the process of end milling of aluminium-lithium alloy could be more efficient and shorter.

The other two elements of the cutting process, cutting speed and feed speed have significant influence on roughness. As is already known from the theory, this testing proves that the less roughness means minor feed speed and bigger cutting speed. This conclusion are reliable only for this material, used tool and the other testing conditions and equipment which were being used in these testing.

Future research will be focused on the other materials of workpieces as well as on the other operation of machining with cutting, i.e. drilling, grinding, etc. and this paper is one small step in the future study of influence of technology parameters on surface roughness of aluminium-lithium alloys.

\section{Acknowledgment}

Authors wish to thank the Federal ministry of education and science of Federation of Bosnia and Herzegovina for financial support in purchasing of the device Hommel-Etamic W5 for testing of surface roughness. This support helped student author to perform the experiments in master thesis in order to finish her master degree study

\section{References}

[1] Šavar, Š. (1990). Obrada metala rezanjem, svezak 2, Školska knjiga, Zagreb, Croatia

[2] Kubatova, D. \& Melichar, M. (2018). Effect of Scanning Speed when Measuring Surface Roughness, Proceedings of the 29th DAAAM International Symposium, ISBN 978-3-902734-20-4, ISSN 1726-9679, B. Katalinic (Ed.), pp.1249-1255, Published by DAAAM International, Vienna, Austria, DOI: 10.2507/29th.daaam.proceedings.180

[3] Zaujec, R.; Vopat, T.; Simna, V. \& Pokorny, P. (2017). The Influence of CAM Strategies on the Tool Wear and Surface Roughness, Proceedings of the 28th DAAAM International Symposium, ISBN 978-3-902734- 11-2, ISSN 1726-9679, B. Katalinic (Ed.), Published by DAAAM International, pp.0803-0811, Vienna, Austria, DOI: 10.2507/28th.daaam.proceedings. 113

[4] Hronek, O. \& Zetek, M. (2017). The Influences of Cutting Edge Radius on Surface Roughness when Milling Nickel Alloy, Proceedings of the 28th DAAAM International Symposium, ISBN 978-3-902734-11-2, ISSN 1726-9679, B. Katalinic (Ed.), Published by DAAAM International, pp.1037-1043, Vienna, Austria, DOI: 10.2507/28th.daaam.proceedings. 144

[5] Zetkova, I.; Jenicek, S.; Hronek, O.; Kotesovec, V.; Vrtacek, J. \& Zetek, M. (2018). Influences of Cutting Process Parameters on the Cutting Quality when Water Jet Cutting, Proceedings of the 29th DAAAM International Symposium, ISBN 978-3-902734-20-4, ISSN 1726-9679, B. Katalinic (Ed.), Published by DAAAM International, pp.1286-1292, Vienna, Austria, DOI: 10.2507/29th.daaam.proceedings.185

[6] Mou H.; Huang X.; Zhang X. \& Ding H. (2013) Experimental Study of Surface Integrity of Aluminum Lithium Alloy by Face Milling, International Conference on Intelligent Robotics and Applications. ICIRA 2013, ISBN 978-3-642-40849-6, Lee J., Lee M.C., Liu H., Ryu JH. (eds), Published by Springer, Berlin, Heidelberg, Germany, pp. 491-502, DOI: https://doi.org/10.1007/978-3-642-40849-6_50

[7] Mee, R. (2009). A Comprehensive Guide to Factorial Two-Level Experimentation, Springer-Verlag, ISBN 978-0387-89102-6, New York, USA

[8] https://metal-kovis.hr/shop/cijena/glodalica-prvomajska-g-01, Accessed on 2019-05-15

[9] http://skutor.ba/en/proizvodi, Accesed on 2019-08-24

[10] https://www.jenoptik.com/products/metrology/roughness-and-contour-measurement/roughness-measuring/mobileroughness-measuring-instrument-w5, Accesed on 2019-05-16

[11] Knežević, A. (2019). Ispitivanje parametara hrapavosti elemenata obrađenih glodanjem, M.S. Master thesis, Department of Productional Engineering, University of Mostar, Mostar, Bosnia-Herzegovina 